\title{
Study of the keeping quality of cheese dip stored in PET Bottles: Sensory, physico- chemical, textural and microbiological aspects
}

\author{
Venus Bansal ${ }^{1}$, Suresh Kumar Kanawjia ${ }^{2}$, Yogesh Khetra $^{3}$, and Anindita Debnath ${ }^{4}$
}

Received: 17 February 2021 / Accepted: 09 August 2021 / Published online: 31 October 2021

(C) Indian Dairy Association (India) 2021

\begin{abstract}
This study aimed to evaluate the storage stability of novel cheese dip (CD) and cheese dip with spices (SCD) stored in PET bottles at refrigeration temperature $\left(4 \pm 1^{\circ} \mathrm{C}\right)$. The change in quality attributes in terms of sensory, chemico-physical $(\mathrm{pH}$, acidity, thiobarbituric acid (TBA), acid degree value (ADV) and color $\left(\mathrm{L}^{*}, \mathrm{a}^{*}, \mathrm{~b}^{*}\right)$ textural and microbiological (total plate count, coliform and yeast and mold) were studied at an interval of 10 days. Also, linear regression models were developed to correlate the changes in attributes with storage time. Keeping quality of both $\mathrm{CD}$ and SCD decreased over the period of time. An increase in firmness, SPC, YM, TBA, and ADV was observed for both the samples, whereas $\mathrm{pH}$, adhesiveness, and sensory scores decreased. On day $30, \mathrm{SCD}$ exhibited significantly lower acidity, $\mathrm{ADV}$, TBA, tyrosine, and microbial count than the CD. Also, the sensory scores of SCD were significantly higher compared to $\mathrm{CD}$. Linear regression equations between days and quality attributes showed a determination coefficient $\left(R^{2}\right)>0.85$. This study clearly shows that keeping the quality of cheese dip depends on the composition and ingredients used for its manufacturing. In conclusion, the spoilage of $\mathrm{CD}$ is mainly accompanied by an increase in acidity due to the growth of microorganisms responsible for decreased sensory scores and changes in textural properties of the product. Accordingly, the heating time-temperature combination can be altered to further improve the keeping quality of the product at refrigeration temperature.
\end{abstract}

Venus Bansal, Suresh Kumar Kanawjia, Yogesh Khetra and Anindita Debnath

Dairy Technology Division, ICAR-National Dairy Research Institute, Karnal-132001, Haryana, India.

Email: aninditadebnath2009@gmail.com

Venus Bansal $(\bowtie)$

Department of Dairy Technology, College of Dairy Science and Technology, Guru Angad Dev Veterinary and Animal Sciences University, Ludhiana-141004, Punjab, India.
Keywords: Cheese dip, PET bottles, Preservation, Quality, Shelf life

\section{Introduction}

Understanding the relationship between food storage and quality attributes is vital for several aspects from manufacturer to consumers. The study of change in sensory, physico-chemical, textural, and microbiological attributes of foods is strategic to predict the shelf life, selection of packaging material, and storage conditions required to maintain the quality of food products. Moreover, an appropriate shelf life endorses that quality food is available for consumers. Directly related and interlinked, food packaging is the concept of shelf life. CD known also called as processed liquid cheese, is one of the key variants of processed cheese (PC) in the market now-a-days. It has gained consumer acceptance because of its multifarious uses, from a pleasing appetizer to providing unique flavor to several dishes and foods (Saad et al. 2016; Salek et al. 2019; Szafrańska and Sołowiej, 2019). However, owing to the unorganized production of $\mathrm{CD}$, there is no knowledge regarding the behavior of $\mathrm{CD}$ during storage.

According to Orbis Research (2017), the cheese sauce (CS) and cheese dip market will boom by several million dollars by 2022 . Like other variants of processed cheese, the $\mathrm{CD}$ is an oil-in-water type emulsion that can be prepared by blending various dairy and non-dairy based ingredients (Bansal et al. 2017; Shalaby et al. 2017; Přikryl et al. 2018; Černíková et al. 2017). However, owing to higher moisture content, $\mathrm{CD}$ may have a lower shelf life than other variants of processed cheese. Furthermore, lower salt to moisture ratio (1.4-1.6\%) and higher $\mathrm{pH}$ might cause faster deterioration of $\mathrm{CD}$ during storage. Moreover, due to no strict standards and legal definitions for $\mathrm{CD}$, manufacturers use several dairy and non-dairy-based ingredients for their manufacturing which might affect the storage stability of the product. Researchers have utilized different ingredients (acid casein, whey proteins, skim milk curd, skim milk powder, soy protein concentrate, milk protein concentrate) for the manufacturing of $\mathrm{CD}$ or CS and have studied quality aspects during storage (Saad et al. 2015, 2016; Shalaby et al. 2017). Saad et al. (2015) tested the impact of different preservatives on the storage stability of CS. 
The authors reported a significant increase in the shelf life of cheese dip with added nisin and potassium sorbate mixture.

No single study has been reported that shows the development and consequently storage stability of the product. Also, the effect of the addition of natural spices on the keeping quality of CD has not been reported in the literature. In a previous study (Bansal et al. 2017), the influence of different ingredients viz., cheddar cheese, milk fat, sodium caseinate, and whey proteins on the sensory, physico-chemical, textural, and rheological properties of $\mathrm{CD}$ were studied using rotatable central composite design of response surface methodology. The solution containing $6 \%$ cheddar cheese, $8.82 \%$ protein blend (20:80 of sodium caseinate to WPC-70), and $9.72 \%$ cream yielded maximum desirability.

The current study focused on the effect of storage on the sensory (flavor, BT, CA), hardness, and adhesiveness for optimized CD and $\mathrm{CD}$ with $0.3 \%$ roasted cumin powder as developed in a previous study by Bansal et al. (2017, 2019). The optimized products were hot filled in PET bottles for its stability evaluation at refrigeration temperature. The change in physico-chemical properties viz., moisture content, $\mathrm{pH}$, acidity, TBA, ADV, and color $\left(\mathrm{L}^{*}, \mathrm{a}^{*}, \mathrm{~b}^{*}\right)$ were also evaluated. The microbiological profile including SPC, coliforms, and YM counts were observed throughout the storage period.

\section{Materials and Methods}

\section{Materials}

Cheddar cheese of three months old was procured from the Experimental Dairy Plant, ICAR-National Dairy Research Institute, Karnal. The cream was separated from mixed milk, and the fat content was adjusted to $60 \pm 1 \%$. In the current study, whey protein concentrate (WPC-70) and sodium caseinate were procured from Mahaan Proteins Pvt. Ltd., Mathura, Uttar Pradesh, India. Carboxy methylcellulose from Merck Specialties Pvt. Ltd., Mumbai, India, was used. In addition, tri-sodium citrate was obtained from Posy Pharmaceutical Ltd, Ahmedabad, Gujarat, India; Sigma Aldrich, Mumbai, India, supplied glycerol monostearate. Polyethylene terephthalate (PET) bottles of 180 $\mathrm{ml}$ capacity (M/s Alpha packaging, Surat) were procured from the local market of Karnal, Haryana, India.

\section{Cheese dip manufacturing and storage}

CD and SCD were manufactured as described by Bansal et al. $(2017,2019)$ with the optimized level of cheddar cheese $(6 \%)$, protein blend $(8.82 \%)$, and cream $(9.72 \%)$ and $0.3 \%$ roasted cumin for SCD. A batch size of $10 \mathrm{Kg}$ for both $\mathrm{CD}$ ad SCD was prepared in duplicate to carry out the analysis during storage. The products were hot-packed in pre-sterilized PET bottles and stored at refrigeration $\left(4 \pm 1^{\circ} \mathrm{C}\right)$ temperature till further analysis. The products were evaluated at an interval of 10 days for different quality parameters.

\section{Sensory analysis}

For the sensory evaluation, a descriptive score card was used. A 25 point score card with 12 points for flavor, 9 points for BT, and 4 points for $\mathrm{CA}$ was applied to compare $\mathrm{CD}$ during the storage. The evaluation was carried out by eight panelists well trained with the sensory evaluation of milk and milk products. All the panelists were working as scientists at the Dairy Technology Division of ICAR-NDRI, Karnal, India. The panelists received 20 $\mathrm{g}$ of sample in plastic cups at refrigeration temperature accompanied with a disposable spoon. The judging of products was carried out in booths with proper environmental surroundings.

\section{Physico-chemical properties}

The cheese dip samples were analyzed for moisture content according to the Association of Analytical Official Chemists (AOAC, 2005). The oxidation of milk fat in terms of Thiobarbituric acid value was measured as the method described by Tarladgis et al. (1960). The degree of lipolysis (Acid degree value) was evaluated as per the procedure delineated by Deeth-Fitzgerald and Wood (1975). The $\mathrm{pH}$ of the samples was measured by inserting a glass tip electrode of calibrated $\mathrm{pH}$ meter. The temperature of the sample was maintained at $25 \pm 1^{\circ} \mathrm{C}$ before analyzing $\mathrm{pH}$.

The change in color during storage was measured using a Hunter colorimeter (Reston, Virginia, USA). The instrument was calibrated each time before use. Samples were filled densely up to $1 \mathrm{~cm}$ in height in the glass sample container. Color values were analyzed by CIELAB software and presented in terms of $\mathrm{L}^{*}, \mathrm{a}^{*}, \mathrm{~b}^{*}$. These values represent black (0) to white (100), red (+) to green (-), and yellow $(+)$ to blue $(-)$, respectively.

\section{Textural properties}

Instrumental textural attributes were measured on a Texture Analyser, model-TAXT2i (Stable Micro Systems, Godalming, Surrey, UK). A load cell of $25 \mathrm{~kg}$ with a P-25 cylindrical aluminum probe was used for measuring the textural attributes of CD and SCD. Samples were removed from the refrigerator and packed to a constant weight of $35.5 \mathrm{~g}$ in a sample container. Each sample was taken from the refrigerator and immediately compressed at 1 $\mathrm{mms}^{-1}$ to a strain of $30 \%$ with $0.10 \mathrm{~N}$ force. Textural properties viz. firmness and adhesiveness were computed from the force-time curve. The in-built software viz., texture expert for windows (version 1.20, Stable Micro System) was used to compute the firmness and adhesiveness. Samples were evaluated in triplicate at a storage temperature of the product $\left(5 \pm 1^{\circ} \mathrm{C}\right)$.

\section{Microbiological profile}

For microbiological analysis of cheese, $11 \mathrm{~g}$ of cheese sample was diluted with $99 \mathrm{~mL}$ dilution blank for making the first dilution. 
All other dilutions were made successively using a $9 \mathrm{~mL}$ dilution blank. The dilution blanks were prepared by mixing $2 \%$ sodium citrate and $0.9 \%$ sodium chloride followed by autoclaving at $121^{\circ} \mathrm{C}$ for 20 minutes. The SPC, coliform, and YM counts were enumerated by surface plating in triplicate on plate count agar, violet red bile agar, and potato dextrose agar, respectively. The petri plates were kept at $37^{\circ} \mathrm{C}$ for the growth of SPC and coliform and at $25^{\circ} \mathrm{C}$ for yeast $\&$ mold count. The growth of colonies was counted after $48 \mathrm{~h}$ for SPC and coliform, while yeast and mold counts were enumerated after 3-5 days. The results were presented in a number of colonies per gram of sample. All agar for surface plating was procured from HiMedia (Bombay, India).

\section{Statistical analysis}

Data were analyzed using the IBM SPSS Statistics 20 software package. A two-way Analysis of variance (ANOVA) was performed to find significant differences among various quality parameters during storage. Means with p-value $<0.05$ were considered statistically different. Coefficient of determination was evaluated to validate the linear regression analysis.

\section{Results and Discussion}

\section{Sensory analysis}

Table 1 shows the change in flavor, BT, and CA scores of CD and SCD with the progress of the storage period. The flavor score of CD and SCD decreased significantly $(\mathrm{p}<0.05)$ from 10.83 to 8.12 and 11.37 to 10.37 , respectively, on the 30 th day of the storage period. During 30 days of study, change in flavor scores were 2.71 and 1.0 units, respectively, for $\mathrm{CD}$ and SCD. Moreover, it was observed that flavor scores were significantly different between the samples from day 1. Similarly, BT and CA scores decreased for both the samples throughout the storage study. The BT scores of CD decreased to 7.41 from 8.08, and for SCD, it decreased to 7.50 from 8.25. Thus, the decrease in BT scores for $\mathrm{CD}$ and $\mathrm{SCD}$ was significant $(\mathrm{p}<0.05)$ during the storage study. Sensory CA scores also decreased significantly for both the samples with storage time. However, there was a nonsignificant difference in CA scores among the samples on the same storage day.

The results are concomitant with the previous works reported by Saad et al. (2015) and Desouky et al. (2019) for processed cheese products. The decrease in sensory attributes with the progress of storage might be because of an increase in the bacterial count and consequently an increase in free fatty acids and acidity. Although, the lesser reduction in flavor scores of SCD might be owing to the preservative effect of cumin. Similar results have been testified by Cakir et al. (2016) for Erzincan Tulum cheese. The authors reported better liking of the samples containing cumin seeds in comparison to control cheese. In consistent to above results, previous studies have concluded that an increase in acidity might lead to a deterioration of the product (Kapoor and Metzger, 2008; Hamad and Ismail, 2013). Therefore, the present study results suggested that addition of cumin to $\mathrm{CD}$ might improve the sensory profile of the product due to a lesser increase in acidity over 30 days compared to $\mathrm{CD}$ without cumin.

\section{Physico-chemical properties}

Table 2 depicts the change in moisture content of samples over 30 days at refrigeration temperature. A significant $(\mathrm{p}<0.05)$ reduction in moisture content for both $\mathrm{CD}$ and $\mathrm{SCD}$ was observed with the progress of storage. A change of 1.21 units was observed from 1st day of storage to the 30th day of storage for CD. At the same time, the moisture content of SCD decreased by 0.85 units during 30 days of storage study. The non-significant differences in moisture content of both the samples might be because of the addition of cumin and consequently usage of the same amount of less water during product manufacturing as described in previous studies (Bansal et al. 2017; 2019). Further, a decrease in moisture content during storage might be owing to the evaporation of free available water in the sample. The results are in agreement with the previous study reported by Rafiq and Ghosh (2018). In another study, Ney (1988) stated that storage of PC for 30 days at $20^{\circ} \mathrm{C}$ could cause a weight loss of $2-5 \mathrm{~g} / \mathrm{Kg}$.

Table 1 Change in sensory scores of CD and SCD over 30 days of storage

\begin{tabular}{llllll}
\hline \multicolumn{2}{l}{ Dependent variable } & Sample & \multicolumn{3}{l}{ Storage days } \\
\cline { 2 - 5 } & & 1 & 10 & 20 & 30 \\
\hline Flavor & CD & $10.83 \pm 0.25^{\mathrm{aA}}$ & $9.83 \pm 0.31^{\mathrm{bB}}$ & $8.75 \pm 0.23^{\mathrm{cB}}$ & $8.12 \pm 0.49^{\mathrm{dB}}$ \\
& $\mathrm{SCD}$ & $11.37 \pm 0.44^{\mathrm{aA}}$ & $11 \pm 0.31^{\mathrm{abA}}$ & $10.83 \pm 0.47^{\mathrm{bA}}$ & $10.37 \pm 0.48^{\mathrm{cA}}$ \\
BT & $\mathrm{CD}$ & $8.08 \pm 0.14^{\mathrm{aA}}$ & $7.75 \pm 0.09^{\mathrm{bB}}$ & $7.54 \pm 0.15^{\mathrm{cB}}$ & $7.41 \pm 0.17^{\mathrm{cA}}$ \\
& $\mathrm{SCD}$ & $8.25 \pm 0.11^{\mathrm{aA}}$ & $8.12 \pm 0.09^{\mathrm{aA}}$ & $7.92 \pm 0.07^{\mathrm{bA}}$ & $7.5 \pm 0.09^{\mathrm{cA}}$ \\
CA & $\mathrm{CD}$ & $3.87 \pm 0.08^{\mathrm{aA}}$ & $3.41 \pm 0.23^{\mathrm{bA}}$ & $3.29 \pm 0.13^{\mathrm{bA}}$ & $3 \pm 0.09^{\mathrm{cA}}$ \\
& $\mathrm{SCD}$ & $3.9 \pm 0.05^{\mathrm{aA}}$ & $3.7 \pm 0.1^{\mathrm{bA}}$ & $3.5 \pm 0.18^{\mathrm{cA}}$ & $3.12 \pm 0.05^{\mathrm{dA}}$ \\
\hline
\end{tabular}

Means with different small letter superscripts within a row shows significant difference $(\mathrm{p}<0.05)$ within the sample during storage study

Means with capital letter superscripts within a column shows significant $(\mathrm{p}<0.05)$ difference between the samples at same storage day 
Table 2

The degradation of lactose to lactic acid and consequently change in $\mathrm{pH}$ and acidity of $\mathrm{CD}$ and SCD during 30 days of storage are represented in Table 2 . With the progress of storage, it was noted that the acidity increased while $\mathrm{pH}$ decreased for all the samples. The $\mathrm{pH}$ of CD and SCD decreased from 6.58 to 6.03 and 6.34 , respectively. The lactic acid content of CD and SCD increased to $0.46 \%$ and $0.31 \%$, respectively, on the 30 th day of storage from $0.20 \%$ on the 1 st day of storage. Nevertheless, a significant $(\mathrm{p}<0.05)$ change in $\mathrm{pH}$ and acidity of CD and SCD during the storage period. Furthermore, the samples exhibited significant differences between them after the 10th day of storage. The decrease in $\mathrm{pH}$ with the progress of storage might be because of the breakdown of lactose to lactic acid by heat-resistant microorganisms in the product. In previous studies, similar trends have been testified by Shalaby et al. (2017) and Salek et al. (2019) for processed cheese sauces. Moreover, Awad et al. (2002) and El-Mahdi et al. (2014) specified that change in $\mathrm{pH}$ could also be because of change insoluble nitrogen and decomposition of emulsifying salts and their interaction with proteins. The lesser increase in acidity of SCD than CD might be due to the antimicrobial properties of cumin. Rabita et al. (2006) stated that the addition of spices to cheeses suppresses the growth of microbes and consequently increase in acidity.

Changes in the chemical indicator of oxidative rancidity (TBA) in $\mathrm{CD}$ and SCD during storage are shown in Table 2. TBA value increased in all the cheese samples for 30 days of storage. Before day 10 , samples did not show significant differences $(\mathrm{p}>0.05)$ in TBA value between CD and SCD. However, from day 10-30, all samples were statistically significant $(p<0.05)$ in terms of TBA value. On day 30 , TBA values of $\mathrm{CD}$ and SCD increased from 0.0097 to 0.034 and 0.026 , respectively. These outcomes specify that cheese sauce with added cumin had better resistance to oxidative rancidity. Thippeswamy and Naidu (2005) studied the antioxidant potency of cumin and concluded that cumin is an effective inhibitor of free radical-mediated lipid oxidation. Nevertheless, the increase in TBA value with storage might be due to oxygen present in the packed product headspace and the diffusion of oxygen through the PET bottles. In previous studies, researchers have reported increased lipid oxidation during the storage of milk fat (Olmedo et al. 2013; Smet et al. 2008; Pettersen et al. 2005).

Lipolysis is one of the major chemical changes that deteriorates the quality of stored foods and limits shelf life. It can be observed from Table 2 that ADV increased for both the samples as the storage phase progressed. Moreover, the samples were significantly different $(p<0.05)$ in ADV from day 10 . The increase in FFA might be due to the proliferation of yeast and molds as storage progress. Similar results have been reported for processed cheese during 30 days of storage by Rafiq and Ghosh (2018). Many scientists have tried spices and their essential oils to reduce lipolysis during the storage of food products (Ayar, 2002; Quiroga et al. 2013). In another study, Halamova et al. (2010) testified the antifungal properties of cumin seeds quinones against dairy

Table 2 Effect of storage on physico-chemical attributes of CD and SCD

\begin{tabular}{|c|c|c|c|c|c|}
\hline \multirow[t]{2}{*}{ Dependent variable } & \multirow[t]{2}{*}{ Sample } & \multicolumn{3}{|c|}{ Storage days } & \multirow[b]{2}{*}{30} \\
\hline & & 1 & 10 & 20 & \\
\hline \multirow[t]{2}{*}{ Moisture } & $\mathrm{CD}$ & $76.53 \pm 0.11^{\mathrm{aA}}$ & $76.32 \pm 0.14^{\mathrm{aA}}$ & $75.66 \pm 0.09^{\mathrm{bA}}$ & $75.32 \pm 0.18^{\mathrm{cA}}$ \\
\hline & $\mathrm{SCD}$ & $75.91 \pm 0.08^{\mathrm{aB}}$ & $75.73 \pm 0.1^{\mathrm{abB}}$ & $75.44 \pm 0.07^{\mathrm{bB}}$ & $75.06 \pm 0.09^{\mathrm{cA}}$ \\
\hline \multirow[t]{2}{*}{$\mathrm{pH}$} & $\mathrm{CD}$ & $6.58 \pm 0.002^{\mathrm{aA}}$ & $6.31 \pm 0.01^{\mathrm{bB}}$ & $6.17 \pm 0.07^{\mathrm{cB}}$ & $6.03 \pm 0.003^{\mathrm{dB}}$ \\
\hline & $\mathrm{SCD}$ & $6.58 \pm 0.002^{\mathrm{aA}}$ & $6.55 \pm 0.02^{\mathrm{abA}}$ & $6.47 \pm 0.01^{\mathrm{bA}}$ & $6.34 \pm 0.04^{\mathrm{cA}}$ \\
\hline \multirow[t]{2}{*}{ Acidity } & $\mathrm{CD}$ & $0.2 \pm 0.002^{\mathrm{aA}}$ & $0.29 \pm 0.003^{\mathrm{bA}}$ & $0.37 \pm 0.011^{\mathrm{cA}}$ & $0.46 \pm 0.004^{\mathrm{dA}}$ \\
\hline & SCD & $0.2 \pm 0.002^{\mathrm{aA}}$ & $0.22 \pm 0.004^{\mathrm{bB}}$ & $0.25 \pm 0.003^{\mathrm{cB}}$ & $0.31 \pm 0.01^{\mathrm{dB}}$ \\
\hline \multirow[t]{2}{*}{ TBA } & $\mathrm{CD}$ & $0.0097 \pm 0.001^{\mathrm{aA}}$ & $0.015 \pm 0.002^{\mathrm{bA}}$ & $0.024 \pm 0.002^{\mathrm{cA}}$ & $0.034 \pm 0.002^{\mathrm{dA}}$ \\
\hline & SCD & $0.0097 \pm 0.001^{\mathrm{aA}}$ & $0.013 \pm 0.001^{\mathrm{aA}}$ & $0.019 \pm 0.001^{\mathrm{bB}}$ & $0.026 \pm 0.002^{\mathrm{cB}}$ \\
\hline \multirow[t]{2}{*}{ ADV } & $\mathrm{CD}$ & $0.318 \pm 0.078^{\mathrm{aA}}$ & $0.664 \pm 0.09^{\mathrm{abA}}$ & $0.89 \pm 0.22^{\mathrm{bA}}$ & $1.7 \pm 0.295^{\mathrm{cA}}$ \\
\hline & SCD & $0.318 \pm 0.078^{\mathrm{aA}}$ & $0.503 \pm 0.09^{\mathrm{abB}}$ & $0.63 \pm 0.08^{\mathrm{abB}}$ & $0.85 \pm 0.17^{\mathrm{bB}}$ \\
\hline \multirow[t]{2}{*}{$L^{*}$} & $\mathrm{CD}$ & $86.44 \pm 0.04^{\mathrm{bA}}$ & $85.12 \pm 0.018^{\mathrm{dA}}$ & $85.31 \pm 0.02^{\mathrm{cA}}$ & $86.57 \pm 0.017^{\mathrm{aA}}$ \\
\hline & SCD & $75.89 \pm 0.04^{\mathrm{bB}}$ & $74.98 \pm 0.04^{\mathrm{dB}}$ & $75.33 \pm 0.025^{\mathrm{cB}}$ & $76.91 \pm 0.035^{\mathrm{aB}}$ \\
\hline \multirow[t]{2}{*}{$a^{*}$} & $\mathrm{CD}$ & $0.65 \pm 0.01^{\mathrm{bB}}$ & $0.49 \pm 0.03^{\mathrm{cB}}$ & $0.52 \pm 0.035^{\mathrm{cB}}$ & $0.75 \pm 0.014^{\mathrm{aB}}$ \\
\hline & $\mathrm{SCD}$ & $0.98 \pm 0.02^{\mathrm{bcA}}$ & $0.94 \pm 0.015^{\mathrm{cA}}$ & $1.06 \pm 0.05^{\mathrm{bA}}$ & $1.31 \pm 0.016^{\mathrm{aA}}$ \\
\hline \multirow[t]{2}{*}{$b^{*}$} & $\mathrm{CD}$ & $12.62 \pm 0.005^{\mathrm{bA}}$ & $11.96 \pm 0.057^{\mathrm{dA}}$ & $12.37 \pm 0.108^{\mathrm{cA}}$ & $13.11 \pm 0.047^{\mathrm{aA}}$ \\
\hline & $\mathrm{SCD}$ & $10.39 \pm 0.006^{\mathrm{bB}}$ & $10.11 \pm 0.03^{\mathrm{dB}}$ & $10.23 \pm 0.026^{\mathrm{cB}}$ & $11.07 \pm 0.03^{\mathrm{aB}}$ \\
\hline
\end{tabular}

Means with different small letter superscripts within a row shows significant difference $(\mathrm{p}<0.05)$ within the sample during storage study

Means with capital letter superscripts within a column shows significant $(\mathrm{p}<0.05)$ difference between the samples at same storage day 
spoilage yeasts. The authors concluded that it could be used as a natural preservative in the dairy industry.

Color is one of the most critical parameters that define the quality of foods, as it is the first impression to fit in the consumer's mind. The color values of CD and SCD differed significantly $(p<0.05)$ throughout the storage period (Table 2). Between 1 and 10 days of storage, $\mathrm{L}^{*}, \mathrm{a}^{*}$, and $\mathrm{b}^{*}$ values decreased, and after that, an increase in the values was observed. The whiteness values $\left(\mathrm{L}^{*}\right)$ of SCD were lower compared to CD. This might be owing to the added roasted cumin, which gives a blackish tinge to the product. Moreover, the increase in $\mathrm{a}^{*}$ and $\mathrm{b}^{*}$ value with the progress of storage might be owing to the Maillard reaction and /or degradation of proteins throughout storage (Buňka et al. 2008; Banach et al. 2014). The increase in yellowness may also be because of a decrease in moisture content. The results are concomitant with Abd-Rabou et al. (2005) and Azzam (2007), where authors reported an increase in yellowness and a decrease in moisture content throughout the storage study. Also, with the progress of the storage phase, authors have reported lowering the whiteness of cheese (Abd-Rabou et al. 2005; Azzam, 2007). In contrast, Esmer et al. (2009) reported no particular pattern for L*, $a^{*}$, and $b^{*}$ values in Crottin de Chavignol Cheese.

\section{Textural attributes}

The progress of storage was accompanied by a significant $(\mathrm{p}<0.05)$ increase in firmness and a decrease in adhesiveness through 30 days of storage (Table 3). Moreover, the samples were significantly different at each storage day for firmness and adhesiveness. The firmness of CD and SCD increased from 0.284 to 0.371 and 0.292 to 0.385 , respectively, at the end of the storage period. Consequently, the adhesiveness of samples decreased from 0.192 to 0.132 and 0.17 to 0.11 for $\mathrm{CD}$ and $\mathrm{SCD}$, respectively. The change in textural attributes of cheese is affected by several factors, including $\mathrm{pH}$, moisture content, proteolysis, lipolysis (Fox et al. 2020; Kapoor and Metzger, 2008; Tamime, 2011). In general, it has been testified that the progress of storage is accompanied by a decrease in firmness (Delgado et al. 2011; Khosrowshahi et al. 2006) owing to the breakdown of protein into smaller peptides. However, in this study, an increase in firmness with storage time might presumably be because of dominating factor of $\mathrm{pH}$ in comparison to protein breakdown. Several authors have reported the increase in firmness and decrease in adhesiveness of cheese up to a certain period due to lowering of moisture content and decrease in $\mathrm{pH}$ with storage days (Tamime, 2011; Gutiérrez-Méndez et al. 2013; Barukčić et al. 2020). The increase in firmness with a reduction in $\mathrm{pH}$ might be owing to increased interactions between milk proteins at lower pH. Also, according to Awad et al. (2002), firmness increases with storage time, presumably because of the decomposition of emulsifying salts, which reduces the $\mathrm{pH}$.

\section{Microbiological profile}

On day 1 , the SPC count of CD and SCD was $9.77 \times 10^{2} \mathrm{cfu} / \mathrm{g}$. The number of microorganisms detected increased to $2.88 \times 10^{4} \mathrm{cfu} / \mathrm{g}$ for $\mathrm{CD}$ and $2.33 \times 10^{4} \mathrm{cfu} / \mathrm{g}$ for $\mathrm{SCD}$ at the end of 30 days storage period. Further, the samples were significantly $(\mathrm{p}<0.05)$ different at each storage day for SPC (Table 3). The VRBA plate count method used to detect coliforms did not show any coliform throughout the storage period. Also, on day 1, YM was not spotted for both CD and SCD. However, with the progress of storage, the number of YM increased to $2.8 \mathrm{cfu} / \mathrm{g}$ for $\mathrm{CD}$ and 2.6 $\mathrm{cfu} / \mathrm{g}$ for SCD on the 30th day of storage. There were significant $(p<0.05)$ differences in the YM count among the samples at each storage day. The results indicate that the change in quality parameters of CD and SCD could be because of the growth of microorganisms over a period of time. Also, the non-presence of coliforms indicates the good hygienic practices followed in the course of product manufacture. Previous studies have also reported the increase in SPC of cheeses over the period of time (Papaioannou et al. 2007; Dermiki et al. 2008; Esmer et al. 2009a; Smigic et al. 2018). However, the statistical differences between SPC of CD and SCD testified that the addition of cumin to CD

Table 3 Textural and microbiological profile of CD and SCD during 30 days of storage

\begin{tabular}{|c|c|c|c|c|c|}
\hline \multirow[t]{2}{*}{ Dependent variable } & \multirow[t]{2}{*}{ Sample } & \multicolumn{3}{|c|}{ Storage days } & \multirow[b]{2}{*}{30} \\
\hline & & $\overline{1}$ & 10 & 20 & \\
\hline \multirow[t]{2}{*}{ Firmness } & $\mathrm{CD}$ & $0.284 \pm 0.005^{\mathrm{aA}}$ & $0.298 \pm 0.007^{\mathrm{bA}}$ & $0.345 \pm 0.008^{\mathrm{cA}}$ & $0.371 \pm 0.002^{\mathrm{dA}}$ \\
\hline & SCD & $0.292 \pm 0.007^{\mathrm{aB}}$ & $0.318 \pm 0.006^{\mathrm{bB}}$ & $0.365 \pm 0.002^{\mathrm{cB}}$ & $0.385 \pm 0.006^{\mathrm{dB}}$ \\
\hline \multirow[t]{2}{*}{ Adhesiveness } & $\mathrm{CD}$ & $0.192 \pm 0.004^{\mathrm{aA}}$ & $0.167 \pm 0.002^{\mathrm{bA}}$ & $0.155 \pm 0.003^{\mathrm{cA}}$ & $0.132 \pm 0.005^{\mathrm{dA}}$ \\
\hline & SCD & $0.17 \pm 0.004^{\mathrm{aB}}$ & $0.13 \pm 0.006^{\mathrm{bB}}$ & $0.12 \pm 0.003^{\mathrm{cB}}$ & $0.11 \pm 0.003^{\mathrm{dB}}$ \\
\hline \multirow[t]{2}{*}{ SPC } & $\mathrm{CD}$ & $2.99 \pm 0.003^{\mathrm{aA}}$ & $3.89 \pm 0.008^{\mathrm{bA}}$ & $4.22 \pm 0.01^{\mathrm{cA}}$ & $4.46 \pm 0.002^{\mathrm{dA}}$ \\
\hline & SCD & $2.99 \pm 0.003^{\mathrm{aA}}$ & $3.81 \pm 0.004^{\mathrm{bB}}$ & $4.07 \pm 0.002^{\mathrm{cB}}$ & $4.37 \pm 0.002^{\mathrm{dB}}$ \\
\hline \multirow[t]{2}{*}{ YM } & $\mathrm{CD}$ & $\longrightarrow$ & $0.15 \pm 0.045^{\mathrm{a}}$ & $0.41 \pm 0.015^{\mathrm{bA}}$ & $0.45 \pm 0.04^{\mathrm{cA}}$ \\
\hline & SCD & $\longrightarrow$ & 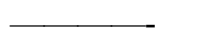 & $0.30 \pm 0.04^{\mathrm{aB}}$ & $0.41 \pm 0.015^{\text {БВ }}$ \\
\hline
\end{tabular}

Means with different small letter superscripts within a row shows significant difference $(\mathrm{p}<0.05)$ within the sample during storage study

Means with capital letter superscripts within a column shows significant $(\mathrm{p}<0.05)$ difference between the samples at same storage day 
Table 4 Regression coefficients and $\mathrm{R}^{2}$ values for the quality attributes of $\mathrm{CD}$ and SCD during storage

\begin{tabular}{|c|c|c|c|c|c|c|}
\hline \multirow[t]{2}{*}{ Indicator } & \multirow[t]{2}{*}{ Dependent variable } & \multirow[t]{2}{*}{ Sample } & \multicolumn{3}{|c|}{ Regression $^{\mathrm{a}}$} & \multirow[b]{2}{*}{$\mathrm{R}^{2}$} \\
\hline & & & $\beta_{0}$ & $\beta_{1}{ }^{\mathrm{b}}$ & Statistical difference & \\
\hline \multirow[t]{6}{*}{ Sensory } & \multirow[t]{2}{*}{ Flavor } & $\mathrm{CD}$ & 10.83 & -0.09475 & $\bar{A}$ & 0.98 \\
\hline & & SCD & 11.39 & -0.03266 & B & 0.97 \\
\hline & \multirow[t]{2}{*}{$B \& T$} & $\mathrm{CD}$ & 8.0421 & -0.0228 & A & 0.95 \\
\hline & & SCD & 8.3345 & -0.0254 & A & 0.94 \\
\hline & \multirow[t]{2}{*}{$\mathrm{C} \& \mathrm{~A}$} & $\mathrm{CD}$ & 3.8192 & -0.0228 & A & 0.94 \\
\hline & & SCD & 3.9552 & -0.0262 & A & 0.98 \\
\hline \multirow[t]{10}{*}{ Physico-chemical } & \multirow[t]{2}{*}{ Moisture } & $\mathrm{CD}$ & 76.634 & -0.0443 & A & 0.97 \\
\hline & & SCD & 75.983 & -0.0294 & A & 0.98 \\
\hline & \multirow[t]{2}{*}{$\mathrm{pH}$} & $\mathrm{CD}$ & 6.552 & -0.01836 & A & 0.96 \\
\hline & & SCD & 6.612 & -0.008295 & B & 0.94 \\
\hline & \multirow[t]{2}{*}{ Acidity } & $\mathrm{CD}$ & 0.1949 & 0.008858 & A & 0.99 \\
\hline & & SCD & 0.1881 & 0.003728 & B & 0.95 \\
\hline & \multirow[t]{2}{*}{ TBA } & $\mathrm{CD}$ & 0.0078 & 0.0008 & A & 0.99 \\
\hline & & SCD & 0.0083 & 0.0006 & B & 0.98 \\
\hline & \multirow[t]{2}{*}{$\mathrm{ADV}$} & $\mathrm{CD}$ & 0.2035 & 0.0452 & A & 0.93 \\
\hline & & SCD & 0.3045 & 0.0178 & B & 0.99 \\
\hline \multirow[t]{4}{*}{ Textural } & \multirow[t]{2}{*}{ Firmness } & $\mathrm{CD}$ & 0.2759 & 0.0032 & A & 0.97 \\
\hline & & SCD & 0.2888 & 0.0034 & A & 0.98 \\
\hline & \multirow[t]{2}{*}{ Adhesiveness } & $\mathrm{CD}$ & 0.1916 & -0.002 & A & 0.98 \\
\hline & & SCD & 0.1621 & -0.0019 & A & 0.85 \\
\hline
\end{tabular}

a Regression equations: $\mathrm{Y}=\beta_{\mathrm{o}}+\beta_{1} \mathrm{X}$; where, $\mathrm{Y}=$ Dependent variable; $\beta_{\mathrm{o}}=\mathrm{a}$ constant that is equal to value of $\mathrm{Ywhen}$ the value of $\mathrm{X}$ $=0 ; \beta_{1}=$ coefficient of $\mathrm{X} ; \mathrm{X}=$ independent variable (Storage time); $\mathrm{R}^{2}=$ coeffieicnet of determination

${ }^{\mathrm{b}}$ The slopes of each varaible and sample followed with the different letters in the column are significantly different at $\alpha=0.05$

suppressed the growth of microflora and thus might aid in the storage stability of CD. Nayra et al. (2002) reported that the YM count in soft cheese was detected after 15 days of storage period. Further, Pereira-Dias et al. (2000) stated that spoilage of processed cheese occurs when the YM is more than 6-7 log cfu/g. This indicates that the change in quality parameters of $\mathrm{CD}$ and $\mathrm{SCD}$ might not be attributed to the growth of YM within the stipulated storage study.

\section{Regression analysis}

The linear regression equations between dependent variables (sensory, physico-chemical, and textural attributes) and independent variable (storage time) for $\mathrm{CD}$ and $\mathrm{SCD}$ are shown in Table 4. In general, the coefficient of determination for linear regression models was more than 0.85 . This indicates that linear regression models were well adjusted and can forecast the change in quality attributes during storage. In $\mathrm{CD}$, higher slopes $(\beta 1)$ of the linear regression equations were detected in the dependent variables ( $\mathrm{pH}$, acidity, TBA, ADV) associated with product deterioration to slopes of SCD regression equations. Also, the regression slope of $\mathrm{CD}$ flavor showed a higher negative value than SCD, indicating faster spoilage of CD than SCD. Thus, regression analysis demonstrates the preserving effect of cumin addition in the cheese dip. Also, Olmedo et al. (2013) and Asensio et al. (2011) testified the preserving effect of different spices viz., oregano, and olive oil in cheese. They testified statistically significant differences among the regression coefficient of the equations. On day 1 , the SPC count of CD and SCD was $9.77 \times$ $10^{2} \mathrm{cfu} / \mathrm{g}$. The number of microorganisms detected increased to $2.88 \times 10^{4} \mathrm{cfu} / \mathrm{g}$ for $\mathrm{CD}$ and $2.33 \times 10^{4} \mathrm{cfu} / \mathrm{g}$ for SCD at the end of 30 days storage period. Further, the samples were significantly $(\mathrm{p}<0.05)$ different at each storage day for SPC (Table 3$)$. The VRBA plate count method used to detect coliforms did not show any coliform throughout the storage period. Also, on day 1, YM was not spotted for both CD and SCD. However, with the progress of storage, the number of YM increased to $2.8 \mathrm{cfu} / \mathrm{g}$ for $\mathrm{CD}$ and $2.6 \mathrm{cfu} / \mathrm{g}$ for SCD on the 30th day of storage. There were significant $(p<0.05)$ differences in the YM count among the samples at each storage day. The results indicate that the change in quality parameters of CD and SCD could be because of the growth of microorganisms over a period of time. Also, the non-presence of coliforms indicates the good hygienic practices followed in the course of product manufacture. Previous studies have also reported the increase in SPC of cheeses over the period of time (Papaioannou et al. 2007; Dermiki et al. 2008; Esmer et al. 2009a; Smigic et al. 2018). However, the statistical differences between SPC of CD and SCD testified that the addition of cumin to $\mathrm{CD}$ suppressed the growth of microflora and thus might aid in the storage stability of CD. Nayra et al. (2002) reported that the YM count in soft cheese was detected after 15 days of storage period. Further, Pereira-Dias et al. (2000) 
stated that spoilage of processed cheese occurs when the YM is more than 6-7 log cfu/g. This indicates that the change in quality parameters of $\mathrm{CD}$ and $\mathrm{SCD}$ might not be attributed to the growth of YM within the stipulated storage study.

\section{Conclusions}

The CD and SCD stored in PET bottles for 30 days showed stability in terms of sensory, chemico-physical, textural, and microbiological parameters. Although storage caused an increase in deterioration parameters for both the samples, these changes did not affect the acceptability of the products. Nevertheless, SCD showed greater stability in terms of textural, chemicophysical, and microbiological parameters, making it more acceptable compared to $\mathrm{CD}$. The change in quality parameters with storage was verified with linear regression models as $\mathrm{R}^{2}$ values for most of the dependent variables were higher than 0.95 .

\section{Acknowledgment}

We want to thanks to Director, National Dairy Research InstituteKarnal for providing basic infrastructural amenities for conducting the presented research work.

\section{Reference}

Abd-Rabou FH, Abd-El Fattah AM, El-Sayed MM, Mohamed AG (2005) Improvement of nutritional value of processed cheese by using modified emulsifying salts. Egypt J Dairy Sci 33:87-95.

AOAC (2005) Official Methods of Analysis. USA: Association of Official Analytical Chemists.

Asensio CM, Nepote V, Grosso NR (2011) Chemical stability of extra virgin olive oil added with oregano essential oil. J Food Sci 76: S445S450.

Awad RA, Abdel-Hamid LB, El-Shabrawy SA, Singh RK (2002) Texture and microstructure of block type processed cheese with formulated emulsifying salt mixtures. LWT35:54-61.

Ayar A (2002) Effect of some herb essential oils on lipolysis in white cheese. J Food Lipids9:225-237.

Azzam MA (2007) Effect of partial replacement of milk fat with vegetable oils on the quality of processed cheese spreads. Egypt J Dairy Sci35:87-95.

Banach JC, Clark S,Lamsal BP (2014) Texture and other changes during storage in model high-protein nutrition bars formulated with modified milk protein concentrates. LWT 56:77-86

Bansal V, Kanawjia SK, Chawla R,Khetra Y, Debnath A, Nigam R (2019) Qualitative effects of milk proteins, stabilizers and variable spice ratio on organoleptic properties of cheese dip. Int J Agric Sci11:83548357

Bansal V, Kanawjia SK, Khetra Y, Puri R, Debnath A (2017) Effect of whey protein concentrate, sodium caseinate, Cheddar cheese, and milk fat on sensory and functional properties of cheese dip. J Food Process Preserv41:e13174

Barukèiæ I, Šèetar M, Marasoviæ I, Jakopoviæ KL, Galiæ K, BožaniæR (2020) Evaluation of quality parameters and shelf life of fresh cheese packed under modified atmosphere. J Food Sci Technol 57:27222731
Buòka F, ŠtitinaJ, Hrabì J (2008) The effect of storage temperature and time on the consistency and color of sterilized processed cheese. Eur Food Res Technol 228:223-229

Cakir Y, Cakmakci S,Hayaloglu AA. (2016) The effect of addition of black cumin (Nigella sativa L.) and ripening period on proteolysis, sensory properties and volatile profiles of Erzincan Tulum (avak) cheese made from raw Akkaraman sheep's milk. Small Ruminant Res 134:65-73

Èerníková M, Nebesáøová J, Salek RN, Øiháèková L, Buòka F (2017) Microstructure and textural and viscoelastic properties of model processed cheese with different dry matter and fat in dry matter content. J Dairy Sci100:4300-4307

Deeth-Fitzgerald HCCH, Wood AFA. (1975) A convenient method for determining the extent of lipolysis in milk. Aust J Dairy Technol30:109

Delgado FJ, González-Crespo J, Cava R, Ramírez R (2011) Proteolysis, texture and colour of a raw goat milk cheese throughout the maturation. Eur Food Res Technol233:483-488

Dermiki M, Ntzimani A, Badeka A, Savvaidis IN, Kontominas MG (2008) Shelf-life extension and quality attributes of the whey cheese "MyzithraKalathaki" using modified atmosphere packaging. LWT41:284-294

Desouky MM, Salama HH, El-Sayed SM (2019) The effects of camel milk powder on the stability and quality properties of processed cheese sauce. Acta Sci Pol Technol Aliment 18:349-359

EL-Mahdi LD, Saad SA, Hassan ZMR, Awad RA (2014) Starch and other stabilizers combinations as thickening agents in processed cheese sauces manufacture. J Food and Dairy Sci5:827-840.

Esmer OK, Balkir P, Seckin AK, Irkin R (2009a) The effect of modified atmosphere and vacuum packaging on the physicochemical, microbiological, sensory and textural properties of Crottin de Chavignol cheese. Food Sci Technol Res 15:367-376.

Esmer O, Balkýr P, Seckýn AK (2009) Changes in chemical, textural and sensory characteristics of Crottin de Chavignol cheese manufactured from frozen curd and pack-aged under modified atmosphere. Milchwissenschaft 64:184-187.

Fox PF, Guinee TP, Cogan TM, McSweeney PLH (2020) Fundamentals of cheese science. Aspen Frederick, USA

Gutiérrez-Méndez NÉSTOR, Trancoso-Reyes NALLELI, Leal-Ramos MY (2013) Texture profile analysis of Fresh cheese and Chihuahua cheese using miniature cheese models. Tecnociencia Chihuahua 7:65-74.

Halamova K, Kokoska L, Flesar J, Sklenickova O, Svobodova B, Marsik P (2010) In vitro antifungal effect of black cumin seed quinones against dairy spoilage yeasts at different acidity levels. J Food Prot 73:22912295.

Hamad MNF, Ismail MM (2013) Improvement of white cheese spread properties: 2. adding of some flavouring agents. J Food and Dairy Sci 4:235-245.

Kapoor R, Metzger LE (2008) Process cheese: Scientific and technological aspects-A review. Compr Rev Food Sci 7:194-214

Khosrowshahi A, Madadlou A, Mousavi MEZ, Emam-Djomeh Z (2006) Monitoring the chemical and textural changes during ripening of Iranian White cheese made with different concentrations of starter. J Dairy Sci 89:3318-3325

Nayra SM, Sharaf OM, Ibrahim GA, Tawfik NF (2002) Incorporation and viability of some probiotic bacteria in functional dairy food I. Soft cheese. Egypt J Dairy Sci 30:217-230

Ney KH (1988)GerätzurMessung des Biegebruchverhaltens von Schmelzkäsescheiben. Alimenta2:31-36

Olmedo RH, Nepote V, Grosso NR (2013) Preservation of sensory and chemical properties in flavoured cheese prepared with cream cheese base using oregano and rosemary essential oils. LWT 53:409-417 
Orbis Research (2017) 2017-2022 Global top countries cheese sauce market report. TX, Dallas

Papaioannou G, Chouliara I, Karatapanis AE, Kontominas MG,Savvaidis IN (2007) Shelf-life of a Greek whey cheese under modified atmosphere packaging. Int Dairy J 17:358-364

Pereira-Dias S, Potes ME, Marinho A, Malfeito-Ferreira M,Loureiro V (2000)Characterisation of yeast flora isolated from an artisanal Portuguese ewes' cheese. Int J Food Microbiol 60:55-63

Pettersen MK, Eie T, Nilsson A (2005) Oxidative stability of cream cheese stored in thermoformed trays as affected by packaging material, drawing depth and light. Int Dairy J15:355-362

Pøikryl J, Hájek T, Švecová B, Salek RN, Ėerníková M, Ėervenka L,Buòka F (2018) Antioxidant properties and textural characteristics of processed cheese spreads enriched with rutin or quercetin: The effect of processing conditions. LWT 87:266-271

Quiroga PR, Grosso NR, Lante A, Lomolino G, Zygadlo JA,Nepote V (2013) Chemical composition, antioxidant activity and anti lipase activity of $\mathrm{O}$ riganumvulgare and Lippiaturbinata essential oils. International JFood SciTechnol 48:642-649

Rabita BAE, Wedad AM, Mohamed OE, Abd E, El-Aziz HM (2006) Effect of cardamom, thyme and clove powder on the composition and quality of white soft cheese made from goat's milk. Assiut J Agric Sci37:139-157

Rafiq S, Ghosh B (2018) Effect of Non-dairy Ingredients on the Quality Characteristics of Processed Cheese during Storage. J Adv Dairy Res $6: 1-4$

Saad SA, El-Mahdi LD, Awad RA, Hassan ZMR (2016) Impact of different food protein sources in processed cheese sauces manufacture. Int J Dairy Sci 11:52-60

Saad SA, El-Mahdi LD, Awad RA,Hassan ZMR (2015) Processed cheese sauces with different preservative systems. Integrative Food Nutr Metabol 2:136-141
Salek RN, Vašina M, Lapèík L, Ėerníková M, Lorencová E, Li P, Buòka F (2019) Evaluation of various emulsifying salts addition on selected properties of processed cheese sauce with the use of mechanical vibration damping and rheological methods. LWT 107:178-184

Shalaby SM, Mohamed AG,Bayoumi HM (2017) Preparation of a novel processed cheese sauce flavored with essential oils. Int J Dairy Sci 12:161-169

Smet K, Raes K, De Block J, Herman L, Dewettinck K,Coudijzer K (2008) A change in antioxidative capacity as a measure of onset to oxidation in pasteurized milk. Int Dairy J 18:520-530

Smigic N, Miocinovic J, Tomic J, Tomasevic I, Rajkovic A, Djekic, I (2018) The effect of nisin and storage temperature on the quality parameters of processed cheese. Mljekarstvo 68:182-191

Szafrañska JO, $\mathrm{So}^{3}$ owiej BG (2020) Cheese sauces: Characteristics of ingredients, manufacturing methods, microbiological and sensory aspects. J Food Process Eng 43:e13364

Tamime AY (2011). Processed cheese and analogues. John Wiley \& Sons, UK

Tarladgis BG, Watts BM, Younathan MT, Dugan JrL (1960) A distillation method for the quantitative determination of malonaldehyde in rancid foods. J Am Oil Chem' Soc 37:44-48

Thippeswamy NB, Naidu KA (2005) Antioxidant potency of cumin varieties - cumin, black cumin and bitter cumin—on antioxidant systems. Eur Food Res Technol 220:472-476 